\title{
A tool for assessing social climate in university classrooms
}

\section{Carles Rostan Sánchez ${ }^{1}$, Dolors Cañabate Ortiz ${ }^{2}$, Mònica González Carrasco ${ }^{1}$, Pilar Albertín Carbo ${ }^{1}$ \& Marc Pérez Burriel $^{1}$}

\footnotetext{
${ }^{1}$ Department of Psychology, University of Girona

${ }^{2}$ Department of Didácticas Específicas, University of Girona
}

This research was partially supported by a grant from the Institut de Recerca Educativa (IRE) of the Universidad de Girona. The authors would like to thank the anonymous reviewers for their valuable comments and suggestions to improve the quality of the paper.

Correspondence to: Carles Rostan Sánchez. Plaça Sant Domènec, 917071 Girona. Spain. carles.rostan@udg.edu

(C) Education \& Psychology I+D+i and Ilustre Colegio Oficial de Psicología de Andalucía Oriental (Spain) 


\begin{abstract}
Introduction. Despite academic climate being a key aspect of teaching quality in academic institutions, few studies conducted in the university context have analyzed this construct systematically.
\end{abstract}

Method. Given the absence of specific tools to apply to university, we propose the construction of a tool for assessing college students' perceptions of their class climate based on an adapted questionnaire regarding social climate in the classroom designed for secondary schools.

Results. The exploratory and confirmatory factor analyses conducted on a sample of 330 college students from different disciplines and years resulted in a 22-item questionnaire with one second-order factor on academic climate separable into three first-order factors (the professor's performance and relationship with the students, affective atmosphere -sense of belonging- and normative behavior, and relationships between students).

Discussion and Conclusion. The Classroom Social Climate Scale for Universities (CSCS-U) has adequate psychometric properties and is a good starting point from which to evaluate classroom climate in the university context.

Keywords: academic social climate, educational quality, psychometric validation, university context assessment.

Reception: 03.24.15 Initial acceptance: 04.19.15 Final acceptance: 07.08.15 


\section{La importancia de los videojuegos en el aprendizaje y el desarrollo de niños de temprana edad}

\section{Resumen}

Introducción. El clima académico es un aspecto clave de la calidad docente de las instituciones académicas, sin embargo, son pocos los estudios realizados en el ámbito universitario en que se ha analizado este constructo de forma sistemática.

Método. Ante la ausencia de instrumentos específicos para ser aplicados en la universidad, hemos planteado la construcción de un instrumento para evaluar la percepción que tienen los estudiantes universitarios del clima de su clase partiendo de la adaptación de un cuestionario sobre clima social en el aula pensado para centros de enseñanza secundaria.

Resultados. Los análisis factorial exploratorio y confirmatorio realizados con una muestra de 330 estudiantes universitarios de diferentes estudios y años han dado como resultado un cuestionario de 22 ítems con un factor de primer orden sobre clima académico disociable en tres factores de segundo orden (actuación del profesor y relación con los alumnos, atmósfera afectiva -sentimiento de pertinencia- y comportamiento normativo, y relación entre los estudiantes).

Discusión y conclusión. La Escala de Clima Social en el Aula para Universidades (ECSA-U) presenta adecuadas propiedades psicométricas y es un buen punto de partida con el que evaluar el clima en el contexto universitario.

Palabras Clave: clima social académico, calidad educacional, validación psicométrica, evaluación del contexto universitario. 


\section{Introduction}

Research into the environment of organizations, understood as the psychosocial characteristics of a place where a group of people perform an activity with a productive purpose, has gained increasingly in importance since the 1960s because, according to the ecological model, it affects the performance, well-being, self-esteem and perceived climate of the group. Early studies led to new avenues of research, including those focusing on educational institutions.

Many terms exist to refer to the environment of organizations, the two most widely used probably being climate and culture. Although the two terms refer to realities that are difficult to distinguish, authors such as Schoen and Teddlie (2008) and Van Houtte (2005) consider it more accurate to differentiate between them due to their different traditions and analysis methods, which may be important in the selection of research strategies and design of organizational improvement plans.

Indeed, while the concept of culture derives from anthropology and uses qualitative ethnographic methods, that of climate stems from psychology and uses quantitative techniques such as questionnaires and statistical analysis. In light of this, a useful distinction would be to consider culture as the values, beliefs and norms shared by a group of people and climate as shared perceptions of behavior (Ashforth, 1985). Our paper is framed within this latter concept of climate and aims to analyze the suitability of a questionnaire designed to measure university students' perceptions of their classroom climate.

Although there is no consensus on the definition of academic climate, some authors have highlighted that it can be considered a property of the university context or a subjective perception of the university by its participants (Rania, Siri, Bagnasco, Aleo, and Saso, 2014). Academic climate includes, among others, topics such as order, trust, academic supports, personal and social relationships among classmates and between professors and students, facilities provided and connectedness (Babalis, 2013; Pérez, Ramos, and López, 2010; Zullig, Koopman, Patton, and Ubbes, 2010). Current studies on academic climate show that it may go unnoticed although it is a determining factor in student involvement and behavior in educational establishments. For example, Macneil, Prater, and Busch (2009) relate academic cli- 
mate with the quality of teaching; and Brookhart and Durkin (2003) with improved academic performance and motivation for school affairs. Brand, Felner, Seitsinger, Burns, and Bolton (2008) suggest that the perception of psychological climate is important for students' adaptation to the academic context, and particularly in the university setting. A positive school climate is an important predictor of school success and healthy behavioral outcomes for students (Hanson, Austin, and Zeng, 2011; Lee van Horn, 2003; Patton et al., 2006). Many studies have found that academic performance, self-esteem, self-efficacy and self-regulation of the task can be modified by students' perception of academic climate (Appleton, Christenson, Kim, and Reschly, 2006; Rania et al., 2014; Urdan, and Schoenfelder, 2006). Machado, Almeida, and Soares (2002) underlined how observed academic experience is important in the construction of vocational and professional identity. According to the literature, understanding the dynamics of climate in the classroom is therefore essential in improving the quality of education and fostering better management, innovation and change (Martín, 2000).

In the Spanish context, climate research has focused on issues such as developing questionnaires to assess the social climate and quality in secondary school (Alonso-Tapia, and Fernández Heredia, 2008; Pérez, Ramos, and López, 2010; Trianes, Blanca, de la Morena, Infante, and Raya, 2006). In addition, Soares, Guisande, Diniz, and Almeida (2006) included social climate in their multidimensional model of young people's transition to university in the Portuguese context.

However, despite contributions to the concept of climate from different fields, Martin (2000) noted that it suffers from a conceptual and operational deficiency and a lack of tools with scientifically developed technical features. Furthermore, most research on academic climate has focused on primary and secondary education, with only very few studies taking an interest in university (Asensio, and Fernández, 1991).

Aims

The aim of our research was to develop and test a questionnaire on social climate in university classrooms, using as a reference the scale developed by Pérez, Ramos, and López (2010). This scale was chosen because it includes the analysis and selection of items from other scales by different authors and due to the fact that the tool resulting from this process has been used previously, although not in the university context. 


\section{Method}

\section{Participants}

The study participants comprised 330 undergraduate students from the University of Girona (Catalonia, Spain), as shown in Table 1. At the time the data were collected for this study, not all undergraduate courses had started, because a transition from the old system to the current one was taking place, hence the higher frequency of students in earlier years. Students belonged to 10 different undergraduate courses offered by three different faculties at the University of Girona. One of them, the Faculty of Education and Psychology, is the largest in terms of number of students.

Table 1. Distribution of participants by course and year $(\mathbf{N}=330)$

\begin{tabular}{lcc}
\hline & Number & Percentage \\
\hline $1^{\text {st }}$ year Education & 32 & 9.7 \\
$1^{\text {st }}$ year Psychology & 32 & 9.7 \\
$2^{\text {nd }}$ year Medicine & 31 & 9.4 \\
$3^{\text {rd }}$ year Psychology & 30 & 9.1 \\
$1^{\text {st }}$ year Art History & 31 & 9.4 \\
$2^{\text {nd }}$ year Psychology & 29 & 8.8 \\
$2^{\text {nd }}$ year Social Education & 30 & 9.1 \\
$1^{\text {st }}$ year Social Work & 46 & 13.9 \\
$2^{\text {nd }}$ year Primary teacher training & 30 & 9.1 \\
$1^{\text {st } y e a r ~ S o c i a l ~ E d u c a t i o n ~}$ & 39 & 11.8 \\
Total & 330 & 100.0 \\
\hline
\end{tabular}

\section{Instrument}

The Classroom Social Climate Scale for Universities (CSCS-U) was developed from the Classroom Social Climate Scale used for ESO (Spanish secondary education) devised by Pérez, Ramos, and López (2010). The latter consists of 44 items grouped into 9 dimensions: interest, satisfaction, relationships, competitiveness, communication, cooperation, rules, cohesion and physical organization. The scale ranges from 1 "Never" to 4 "Always".

First, the questionnaire used for ESO was adapted according to the suitability of each item to the university context. An item was considered to be suitable when it was accepted 
unanimously by the members of the research group. In some cases this led to the resulting item differing markedly from the original (Annex 1). A pilot was then tested on a group of first-year Psychology students to verify ease-of-use and collect suggestions for improvement, which were then incorporated into the questionnaire. Following this, the adapted Spanish version was translated into Catalan using the back-translation procedure. To do this, the Spanish questionnaire was translated into Catalan by a bilingual professor and then translated back into Spanish by another bilingual professor, after which the bilingual research team compared the original version with the back-translated version. No substantial differences were found between them (See Annex 1).

\section{Procedure}

In order to proceed with data collection, study coordinators were first contacted to request their cooperation. The scale was administered by psychology students in classrooms where classes are normally taught. These students had been trained previously to give the same instructions to all participants and clarify any issues that might arise.

\section{Data analysis}

The statistical analysis was performed using SPSS statistical package version 19.0 and AMOS version 18.0. First, an exploratory factor analysis (EFA) was conducted using the principal axis extraction method. The following were applied to extract the number of factors: Kaiser criteria (1958) (eigenvalues greater than 1), the sedimentation test (Cattell's Scree-test, 1966) and parallel analysis (Horn, 1965), using the syntax program for O'Connor's SPSS (2000). We calculated Cronbach's alpha coefficients to analyze the internal consistency of the scale and each of the factors separately.

Confirmatory factor analysis (CFA) was performed using the method of maximum likelihood estimation (ML) once missing values had been imputed by means of regression. To test the model fit, the ratio $\chi^{2}$ was used, and its degree of likelihood, the ratio $\chi^{2} / d f$ (degrees of freedom) and the indices CFI (Comparative Fit Index), RMSEA (Root Mean Square Error of Approximation) and SRMR (Standardized Root Mean Square Residual). RMSEA and SRMR values of less than .05 and .08 , respectively, and CFI greater than .90 indicate a good fit (Hoyle, 1995). Values of between 2 and 5 for the ratio $\chi^{2} / d f$ indicate a good fit to the 
model (Byrne, 1989). We considered that if a model has a good fit using the CFI and RMSEA together, it is very unlikely that the model is not suitable for the data (Herrero, 2010).

\section{Results}

\section{Item description}

Table 2 shows the means and standard deviations for each of the 44 items initially considered in the study. Those obtaining higher means (above 3 on a 4-point scale) are item 31 "The students in our class group are interested in training and becoming competent professionals", item 33 "The Faculty is a nice place to be" and item 38 "In our Faculty we are trained as both professionals and people". Lowest means (under 2 on a 4-point scale) are for negatively worded items, concretely, item 14 "In the classroom I feel lonely, I do not feel accepted by my classmates", item 22 "In this class group, some students are favoured over others", item 29 "The professors ignore our training needs", and item 30 "There is no atmosphere of cooperation between the professors and the student".

Table 2. Descriptive statistics for the items $(\mathrm{N}=330)$

\begin{tabular}{lcc}
\hline & Mean & SD \\
\hline ITEM 1 & 2,30 & .683 \\
ITEM 2 & 2,92 & .688 \\
ITEM 3 & 2,84 & .737 \\
ITEM 4 & 2,82 & .778 \\
ITEM 5 & 2,89 & .762 \\
ITEM 6 & 2,58 & .676 \\
ITEM 7 & 2,48 & .757 \\
ITEM 8 & 2,86 & .797 \\
ITEM 9 & 2,78 & .874 \\
ITEM 10 & 2,38 & .602 \\
ITEM 11 & 2,97 & .640 \\
ITEM 12 & 2,58 & .676 \\
ITEM 13 & 2,45 & .730 \\
ITEM 14 & 1,38 & .701 \\
ITEM 15 & 2,96 & .714 \\
ITEM 16 & 2,70 & .654 \\
ITEM 17 & 2,22 & .889
\end{tabular}




\begin{tabular}{|c|c|c|}
\hline ITEM 18 & 2,34 & .811 \\
\hline ITEM 19 & 2,82 & .666 \\
\hline ITEM 20 & 2,96 & .709 \\
\hline ITEM 21 & 2,87 & .693 \\
\hline ITEM 22 & 1,77 & .725 \\
\hline ITEM 23 & 2,59 & .814 \\
\hline ITEM 24 & 2,71 & .685 \\
\hline ITEM 25 & 2,69 & .760 \\
\hline ITEM 26 & 2,47 & .715 \\
\hline ITEM 27 & 2,46 & .814 \\
\hline ITEM 28 & 2,44 & .687 \\
\hline ITEM 29 & 1,82 & .685 \\
\hline ITEM 30 & 1,85 & .762 \\
\hline ITEM 31 & 3,23 & .570 \\
\hline ITEM 32 & 2,94 & .714 \\
\hline ITEM 33 & 3,11 & .624 \\
\hline ITEM 34 & 2,98 & .505 \\
\hline ITEM 35 & 2,75 & .772 \\
\hline ITEM 36 & 2,08 & .750 \\
\hline ITEM 37 & 2,97 & .467 \\
\hline ITEM 38 & 3,09 & .676 \\
\hline ITEM 39 & 2,83 & .713 \\
\hline ITEM 40 & 2,71 & .841 \\
\hline ITEM 41 & 2,42 & .815 \\
\hline ITEM 42 & 2,13 & .737 \\
\hline ITEM 43 & 2,27 & .811 \\
\hline ITEM 44 & 2,55 & .899 \\
\hline
\end{tabular}

\section{Exploratory factor analysis}

Both the Kaiser-Meyer-Olkin measure of sampling adequacy, with a value of .830, and Bartlett's sphericity test $\left(\chi^{2}(946)=4271.575, p<.001\right)$ indicate the suitability of the data for the EFA. Although 13 factors were extracted using the Kaiser criterion, the scree graph and parallel analysis advise the extraction of 6 factors explaining $42.27 \%$ of the variance (Figure 1). 


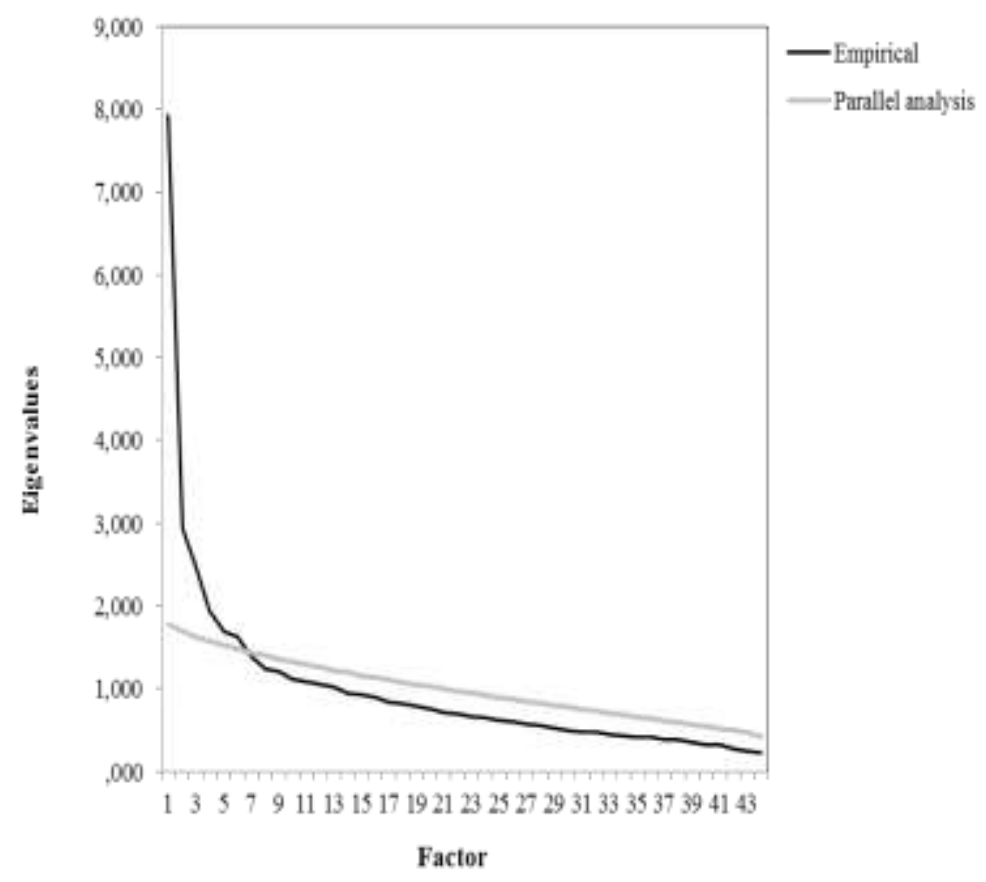

Figure 1. Scree plot and parallel analysis

\section{Confirmatory factor analysis}

After conducting the EFA, the next step was to fit a CFA model considering a single latent factor for climate using the same sample as for the EFA. As Table 3 shows, the fit is far from adequate. Therefore, a model with 6 factors was fit in accordance with the scree graph and parallel analysis results, yielding unsatisfactory fit indices.

Based on the above and following the recommendations of Ferguson and Cox (1993), we removed items with weights above .40 on more than one factor and also those items with a corrected correlation of less than .30 for each of the factors identified in the EFA. Finally, CFA was used to fit a model consisting of 22 items divided among three factors: 1) peer relationships (9 items), 2) professor's performance and relationship between professor and students (7 items), and 3) following rules and sense of belonging (6 items), which requires few error covariances (Figure 2) and has good psychometric properties (Table 3). 
Table 3. Fit indices of the different models calculated for the CSS-U

\begin{tabular}{llllllll}
\hline Model & $\chi^{2}$ & $d f$ & $\chi 2 / d f$ & RMSEA & SRMR & CFI & NFI \\
\hline $\begin{array}{l}\text { Non-orthogonal model with 1 factor } \\
\text { (44 items) }\end{array}$ & 2596.054 & 902 & 2,88 & $.076(.072-.079)$ & .083 & .521 & .421 \\
$\begin{array}{l}\text { Non-orthogonal model with 6 factors } \\
(44 \text { items) }\end{array}$ & 2685.797 & 907 & 2,96 & $.077(.074-.081)$ & .093 & .497 & .401 \\
$\begin{array}{l}\text { Non-orthogonal model with 3 factors } \\
(22 \text { items) }\end{array}$ & 533.184 & 203 & 2,62 & $.070(.063-.078)$ & .076 & .798 & .714 \\
$\begin{array}{l}\text { Orthogonal model with 3 factors } \\
(22 \text { items) (4 error covariances) }\end{array}$ & 342.665 & 199 & 1,72 & $.047(.038-.055)$ & .065 & .912 .816 \\
\hline
\end{tabular}

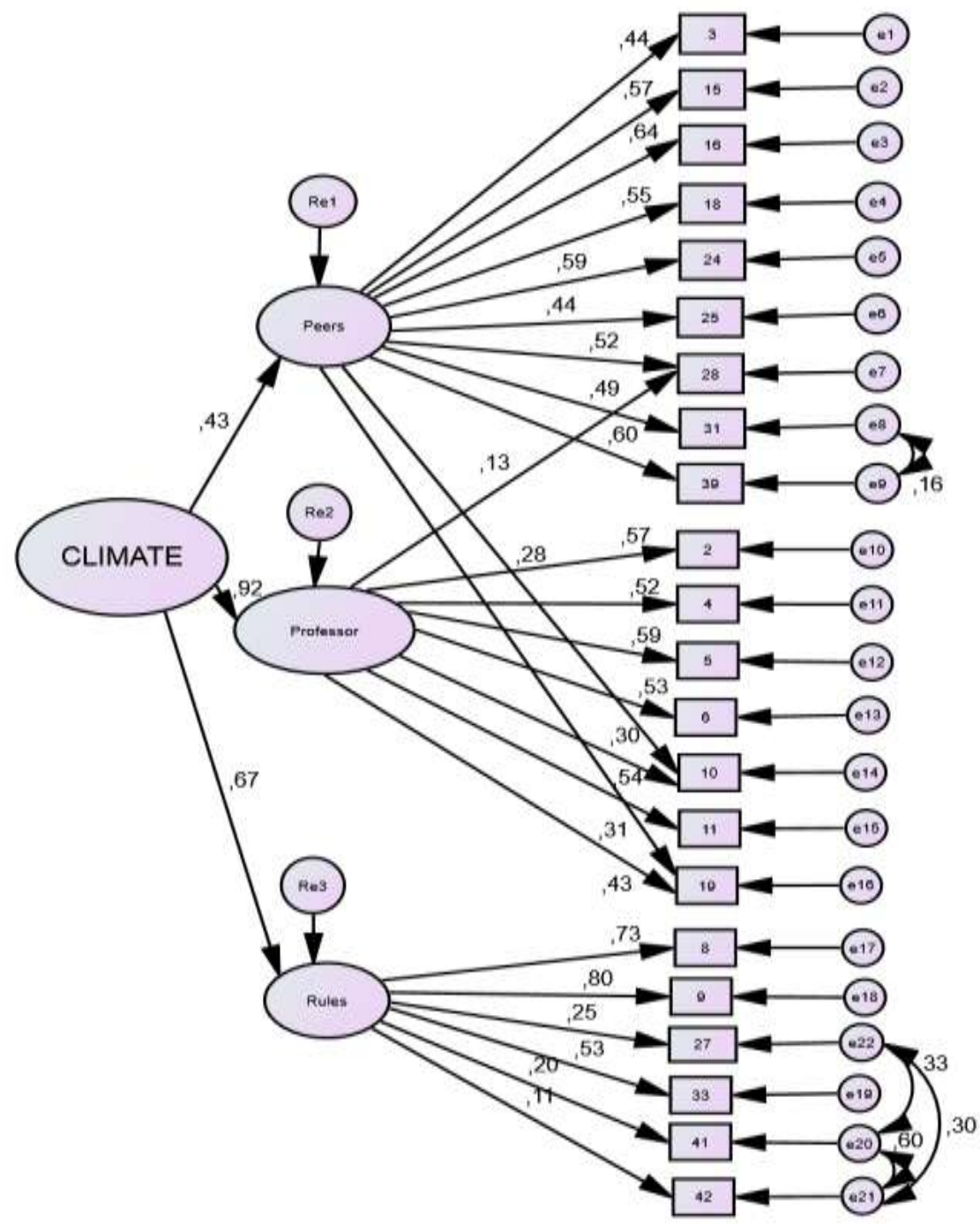

Figure 2. Structure of the standardized weights of items comprising the CSCS-U and their relationship with the construct of climate. 
As can be seen in Figure 2, there are three items, namely 10, 19 and 28, with loads on more than one factor. Adjusting the model meant removing 22 items from the original scale and consequently grouping the remaining items into three factors rather than the 6 proposed by EFA. We can say that factors 1 (Relations with peers) and 2 (Professors' performance and relationships between professor and students) have retained the structure from the EFA, while factor 3 (Rules and belonging to the faculty) comprises items corresponding to factors 3, 4, 5 and 6 in the aforementioned analysis. We also observe the existence of a second-order factor, which we have called climate and the above 3 factors contribute to explaining, particularly Professors' performance and Relationships between professor and students.

Finally, we calculated a Cronbach's alpha of. 84 for the total scale, and a reliability of .79 for factor $1, .74$ for factor 2 and .66 for factor 2 . In other words, internal consistency was high for the total scale and the factors on Peer Relationships and Professor's performance and relationship between professor and students, and moderate in the case of Rules and belonging to the Faculty.

\section{Discussion}

The exploratory factor analysis we conducted initially advised us to reduce the nine dimensions of the original scale to six. We then evaluated four models of the scale by means of CFA. The model that achieves the best fit indices and good psychometric properties is that containing 22 items and 3 factors, with four error covariances. Our final scale therefore saw a decrease from the 44 original items to 22 , and from 9 dimensions to 3 , namely: peer relationships (9 items), professor actions and relationships between professors and students ( 7 items) and following rules and a sense of belonging ( 6 items). The first factor includes items that indicate the quality of the relationship between students of the class group. The second factor refers to the relationship between students and professor. The third factor includes items on the affective atmosphere -sense of belonging- and normative behavior in class. In addition to three first-order factors, the model recognizes the existence of a second-order factor we have called academic climate. Of the three aforementioned factors, the one to make a greater contribution to the second-order factor is that of relations between students and professor, followed by the factor referring to affective atmosphere and normative behavior in class and finally relationship between students. 
Our study shows that academic climate comprises two clearly specific factors (relationship between students and professor, and relationship between students) and a third with items that refer to both affective and normative aspects of the class. It is possible that the inclusion of these two types of items in a single factor is due to the perception that clear and transparent class rules provide students with emotional stability. Both relationships among peers and between students and teachers have already been highlighted in the literature as very important for the school environment, motivation and school adaptation (Babalis, 2013; Brackett, Reyes, Rivers, Elbertson, and Salovey, 2011). Closely related to this, Wentzel (2007; Wentzel, Baker, and Russell, 2009) found that when students feel a sense of emotional support from their teacher, academic support from their peers, and encouragement from their teacher, they are more likely to use self-regulatory strategies and engage in task-related interaction. A similar result was also found by Pianta, Hamre, and Allen (2012). Rules which help to organise the classroom and are perceived as fair and flexible can be an important promoter of social cohesion (Thapa, Cohen, Guffey, and Higgins-D'Alessandro, 2013), while goodquality school climates foster a sense of connection to the school, helping to reduce emotional and behavioural problems (Loukas, Suzuki, and Horton, 2006).

\section{Limitations}

Although the scale resulting from the factor analysis has good psychometric properties for evaluating classroom climate in the university context, it also has some limitations. One is that participating students were mainly from the social sciences, with a small representation of students from the humanities and medicine, but no representation of sciences or engineering subjects, for example. Moreover, as stated in the introduction, the full cycle of undergraduate degree courses had not yet started when we conducted the study, which meant that the majority of students were from the first years and there is little representation of students from later years, who might have displayed more different characteristics due to their greater experience of the university environment. In fact, it would be interesting to compare the perceptions of students when they are in their first and last years to ascertain whether there is any stability in their perception of classroom climate or to conduct longitudinal monitoring of perceived climate among class groups whose composition does not vary over two or more years. Finally, we believe the final model suffers from a lack of representation of students' perceptions regarding their participation in university life, one of the key educational elements of their time 
at university according to the European Space of Higher Education (Michavila, and Parejo, 2008), since the original scale items that referred to this (namely, items 21 and 23) were not retained in the final model.

\section{Future research}

The contribution of this study is the development of an instrument for assessing social climate in the classroom at university level, given the absence of such instruments in the Spanish context. Future research should include larger samples of students at the same university, considering more faculties, more undergraduate and post-graduate courses and more years, but also students enrolled at other universities located in different geographical areas. Longitudinal studies would be of help in order to determine whether the perception of social climate in university classrooms develops over time. Academic climate should also be related to other constructs such as well-being, engagement and academic performance. Some sociodemographic characteristics not considered here such as gender would also be of interest.

\section{References}

Alonso-Tapia J., \& Fernández, B. (2008). Development and initial validation of the Classroom Motivational Climate Questionnaire (CMCQ). Psicothema, 20(4), 883-889.

Appleton, J.J., Christenson, S.L., Kim, D., \& Reschly A.L. (2006). Measuring cognitive and psychological engagement: validation of the Students Engagement Instruments. Journal of School Psychology, 44(5), 427-445. doi: 10.1016/j.jsp.2006.04.002

Asensio, I., \& Fernández, Mª J. (1991). El clima en las instituciones de Educación Superior [The climate in High Education Institution]. Revista Complutense de Educación, 2(3), 501-518.

Ashforth, B.E. (1985). Climate formation: issues and extensions. Academy Management Review, $10(4), 837-847$.

Babalis, T. (2013). The relation of Classroom Climate to Learning. Journal of Modern Education Review, 3(4), 289-301.

Brackett, M.A., Reyes, M.R., Rivers, S.E., Elbertson, N.A., \& Salovey, P. (2011). Classroom Emotional Climate, Teacher Affiliation, and Student Conduct. Journal of Classroom Interaction, 46(1), 27-36. 
Brand, S., Felner, R., Seitsinger, A., Burns, A., \& Bolton, A. (2008). A large study of the assesment of the social environment of middle schools: the validity and utility of teachers' ratings of school climate, cultural pluralism, and safety problems for understanding and assessing the impact of school improvement. Journal of School Psychology, 46(5), 507-535. doi: 10.1016/j.Jsp.2007.12.001

Brookhart, S. M., \& Durkin, D. T. (2003). Classroom assessment, student motivation, and achievement in high school social studies classes. Applied Measurement in Education, 16, 27-54. doi: 10.1207/S15324818AME1601_2

Byrne, B. M. (1989). A primer of LISREL: Basic applications and programming for confirmatory factor analytic models. New York: Springer Verlag.

Cattell, R. B. (1966). The Scree Test for the Number of Factors. Multivariate Behavioral Research, 1, 245-276. doi: 10.1207/s15327906mbr0102_10

Ferguson, E., \& Cox, T. (1993). Exploratory Factor Analysis: A user's guide. International Journal of Selection and Assessment, 1(2), 84-94. doi:10.1111/j.14682389.1993.tb00092.x

Hanson, T., Austin, G., \& Zeng, C. (2011). The relationship of academic achievement and school well-being. San Francisco: WestEd. Summary available for download at http://www.childrennow.org/index.php/learn/beingwelllearningwell.

Herrero, J. (2010). Confirmatory Factor Analysis in the study of the Structure and Stability of Assessment Instruments: An example with the Self-Esteem Questionnaire (CA-14). Intervención Psicosocial,19(3), 289-300. doi: 10.5093/in2010v19n3a9

Horn, J. L. (1965). A Rationale and Test For the Number of Factors in Factor Analysis. Psychometrika, 30, 179-85. doi: 10.1007/BF02289447

Hoyle, R. (1995) (ed.). Structural equation modeling: concepts, issues and applications. USA: Sage Publications.

Kaiser, H.F. (1958). The varimax criterion for analytic rotation in factor analysis. Psychometrika, 23, 187-200. doi: 10.1007/BF02289233

Lee van Horn, M. (2003). Assessing the Unit of Measurement for School Climate through Psychometric and Outcome Analyses of the School Climate Survey. Educational and Psychological Measurement, 63(6), 1002-1019. doi: 10.1177/0013164403251317

Loukas, A., Suzuki, R., \& Horton, K.D. (2006). Examining School Connectedness as a Mediator of School Climate Effects. Journal of Research on Adolescence, 16(3), 491-502. doi: 10.1111/j.1532-7795.2006.00504.x 
Macneil, A. J., Prater, D.L., \& Busch, S. (2009). The effects of school culture and climate on student achievement. International Journal of Leadership in Education, 12 (1), 73-84. doi: 10.1080/13603120701576241

Machado, C.A., Almeida, L.S., \& Soares, A.P.C. (2002). Academic experience at the beginning and the end of university studies. European Journal of Education, 37(4), 387394. doi: 10.1111/1467-3435.00117

Martín, M. (2000). Clima de trabajo y organizaciones que aprenden [Work climate and organitations that learn]. Educar, 27, 103-117.

Michavila, F., \& Parejo, J.L. (2008). Políticas de participación estudiantil en el proceso de Bolonia [Policies of student participation in the Bologna process]. Revista de Educación, 85-118.

O'Connor, B.P. (2000). SPSS and SAS Programs for Determining the Number of Components Using Parallel Analysis and Velicer's MAP Test. Behavior Research Methods, Instruments and Computers, 32, 396-402.

Patton, G.C., Bond, L., Carlin, J.B., Thomas, L., Butker, H., Glover, S., Catalano, R., \& Bowes,G. (2006,). Promoting social inclusion in schools: A group-randomized trial of effects on student health risk behavior and well-being. American Journal of Public Health, 96(9), 1582-1587. doi: 10.2105/AJPH.2004.047399

Pérez, A., Ramos, G., \& López, E. (2010). Clima Social en el Aula: percepción diferenciada de los alumnos de educación secundaria obligatoria [Social Climate in the classroom: Differentiated perception of students in Obligatory Secondary Education]. Cultura y Educación, 22(3), 259-281.

Pianta, R.C., Hamre, B.K., \& Allen, J.P. (2012). Teacher-Student Relationships and Engagement: Conceptualizing, Measuring, and Improving the Capacity of Classroom Interactions. In S.L. Christenson, M.L. Reschli, \& C. Wylie (eds.) Handbook of Research on Student Engagement (pp. 365-385). New York: Springer. doi: 10.1007/978-1-46142018-7_17

Rania, N., Siri, A., Bagnasco, A., Aleo, G., \& Saso, L. (2014). Academic climate, well-being and acdemic performance in a university degree course. Journal of Nursing Management, 22 (6), 751-760. doi: 10.1111/j.1365-2834.2012.01471.x

Schoen, L.T., \& Teddlie, CH. (2008). A new model of school culture: a response to call for conceptual clarity. School Efectiveness and School Improvement, 19(2), 129-153. doi: $10.1080 / 09243450802095278$ 
Soares, A.P., Guisande, M. A., Diniz, A.M., \& Almeida, S.L. (2006). Construcción y validación de un modelo multidimensional de ajuste de los jóvenes al contexto universitario [Construction and validation of a multidimensional model of fit of young people to university context]. Psicothema, 18(2), 249-255.

Thapa, A., Cohen, J., Guffey, S., \& Higgins-D’Alessandro, A. (2013). A Review of School Climate Research. Review of Educational Research, 83(3), 357-385. doi: $10.3102 / 0034654313483907$

Trianes, M.V., Blanca, M.J., de la Morena, L., Infante, L., \& Raya, S. (2006). Un cuestionario para evaluar el clima social del centro escolar [A questionnaire to assess the social climate of the school]. Psicothema, 18(2), 272-277.

Urdan, T. \& Schoenfelder, E. (2006). Classroom effects on student motivation: Goal structures, social relationships, and competence beliefs. Journal of School Psychology, 44(5), 331-349. doi: 10.1016/j.jsp.2006.04.003

Van Houtte, M. (2005). Climate or culture? A Plea for conceptual clarity in School Effectiveness Research. School Effectiveness and School Improvement, 16(1), 71-89. doi: $10.1007 / \mathrm{s} 11205-010-9605-8$

Wentzel, K.R. (1997). Student Motivation in Middle School: The Role of Perceived Pedagogical caring. Journal of Educational Psychology, 89(3), 411-419.

Wentzel, K.R., Baker, S. A., \& Russell, S. (2009). Peer relationships and positive adjustment at school. In R. Gillman, S. Huebner \& M. Furlong (Eds.), Promoting wellness in children and youth: A handbook of positive psychology in the schools (pp. 229-244). Mahwah, NJ: Erlbaum.

Zullig, K.J., Koopman, T.M., Patton,J.M., \& Ubbes, V.A. (2010). School climate: Historical review instrument development, and school assessment. Journal of Psychoeducational Assessment, 28(2), 139-152. doi: 10.1177/0734282909344205 
Annex 1. List of the original items on the Classroom Social Climate Scale by Pérez, Ramos and López (2010) compared to corresponding items adapted to the university context. Scale with 4 response options: never, sometimes, quite often, always.

Classroom Social Climate Scale (ESO) (Pérez, Ramos, and López, 2010)

1.Los profesores se interesan personalmente por cada uno de nosotros

The teachers take a personal interest in all of us

2. Los profesores escuchan a los alumnos sin interrumpir

The teachers listen to the students without interrupting

3. Los profesores muestran respeto por nuestros sentimientos

The teachers show respect for our feelings

4. Los profesores nos enseñan a que respetemos la ideas y los sentimientos de otras personas

The teachers show us how to respect other people's ideas and feelings

5. Los profesores se muestran satisfechos cuando sacamos buenas notas

The teachers are pleased when we get good grades

6. Los profesores felicitan a los alumnos que ayudan a otros compañeros

The teachers congratulate students who help other students

7. Las relaciones entre nosotros y los profesores son agradables

There is a nice relationship between us and the teachers

8. Los alumnos estamos contentos con el grupo clase

We students are pleased with the class group

9. Los alumnos nos sentimos orgullosos de esta clase

We students are proud of this class

10. Me parece que los profesores disfrutan con su trabajo

I think the teachers enjoy their work

11. La relación entre los profesores y los alumnos es cordial

The relationship between the teachers and students is a friendly one
Classroom Social Climate Scale (University)

(CSCS-U)

Translation from Catalan into Spanish and English

1.Los profesores se interesan por nuestra forma-

ción (de una manera personalizada)

The professors take an interest in our education

(in a personalized way)

2. Los profesores miran de resolver las dudas de los estudiantes $(*)$

The professors try to resolve students' questions

3. Respetamos y mostramos interés por todos los compañeros del grupo-clase $(*)$

We respect and show an interest in all of our classmates

4. Los profesores nos transmiten, promueven respeto por las creencias, ideas y sentimientos de las otras personas $(*)$

The professors transmit to us and promote respect for other people's beliefs, ideas and feelings

5. Los profesores se muestran satisfechos cuando mostramos el logro de competencias para la profesión $(*)$

The professors are pleased when we demonstrate having achieved competences suitable for the profession

6. El profesorado facilita la ayuda y cooperación entre nosotros $(*)$

The professors facilitate student-to-student help and cooperation

7. Las relaciones entre nosotros y el personal de administración y servicios de la Facultad es adecuada

The relationship between us and the Faculty administrative and services staff is adequate

8. Los estudiantes estamos a gusto en nuestra Facultad $(*)$

We students are at ease in our Faculty

9. Los estudiantes nos sentimos orgullosos de pertenecer a nuestra Facultad (*)

We students are proud to belong to our Faculty

10. Los estudiantes parecen motivados para asistir a las clases $(*)$

The students seem motivated to attend classes

11. La relación entre los profesores y los estudiantes suele ser cordial $(*)$

The relationship between professors and students is usually a friendly one 
12. A algunos alumnos de mi clase les gusta ser los primeros

Some students in my class like to come first

13. Los alumnos queremos que nuestro trabajo sea mejor que el de nuestros compañeros We students want our work to be better than our classmates'

14. El aula es un lugar dónde me siento solo The classroom is a place where I feel lonely

15. En esta clase, los alumnos nos llevamos muy bien

In this class, the students get along very well

16. En esta clase los alumnos prestamos atención a lo que otros compañeros dicen In this class students pay attention to what their classmates say

17. Los profesores se preocupan porque los alumnos no menospreciemos (o insultemos) a otros compañeros

The teachers are concerned that students do not show contempt for (or insult) their classmates

18. Entre nosotros evitamos menospreciarnos (o insultarnos)

We do not show contempt for (or insult) one another

19. En esta clase los alumnos tenemos muy buena comunicación con los profesores In this class the students have very good communication with the teachers 20. En esta clase los alumnos tenemos muy buena comunicación entre nosotros In this class the students have very good communication with each other

21. La mayor parte de los profesores nos animan a hablar en nuestro grupo clase Most of the teachers encourage us to talk in our class group

22. En esta clase se favorece a algunos alumnos más que a otros

In this class, some students are favored over others
12. Hay compañeros a quienes no les preocupa ningún otro aspecto de su formación que las calificaciones (notas)

I have classmates who do not care about any other aspect of their education than the grades

13. Los estudiantes queremos que los resultados de nuestro trabajo sean mejores que el de los compañeros/eras

We students want the results of our work to be better than our classmates'

14. En el aula me siento solo/a, no me siento acogido por los compañeros

In the classroom I feel lonely, I do not feel accepted by my classmates

15. En nuestro grupo-clase los estudiantes tenemos una buena relación entre nosotros $(*)$

In our class group the students have a good relationship with one another

16. En nuestro grupo-clase los estudiantes muestran interés, atención a las intervenciones y aportaciones de nuestros compañeros $(*)$

In our class group students show interest and listen to our classmates' contributions

17. La universidad lleva a cabo acciones para evitar que hayan conductas de desprecio, discriminación o rechazo

The university takes action to prevent behaviours displaying contempt, discrimination or rejection

18. Los estudiantes llevan a cabo acciones para evitar que hayan conductas de desprecio, discriminación o rechazo hacia otros compañeros $(*)$ Students take actions to prevent behaviours displaying contempt, discrimination or rejection towards classmates

19. En nuestro grupo-clase los estudiantes tenemos muy buena comunicación con los profesores $(*)$ In our class group the students have very good communication with the professors

20. En nuestro grupo-clase los estudiantes tenemos muy buena comunicación entre nosotros

In our class group the students have very good communication with each other

21. La mayoría de profesores nos animan a intervenir en nuestro grupo-clase

Most of the professors encourage us to talk in our class group

22. En nuestro grupo-clase se favorece más a unos estudiantes que a otros

In this class group, some students are favoured over others 
23. Las decisiones de esta clase son adoptadas por todos los alumnos

Decisions are taken by all students in this class

24. Los alumnos colaboramos muy bien entre nosotros

The students work very well together

25. En esta clase se propician debates

Debate is encouraged in this class

26. En esta clase los profesores animan a los alumnos que quieren hacer las cosas de manera distinta

In this class the teachers encourage students who want to do things differently

27. En esta clase, los profesores esperan que los alumnos sigamos las normas

In this class, the teachers expect students to follow the rules

28. En esta clase los profesores y los alumnos nos preocupamos unos de otros

In this class the teachers and students are concerned about each other

29. Nuestros profesores no nos escuchan Our teachers do not listen to us

30. Los alumnos nos llevamos mal con los profesores

The students do not get on with the teachers

31. Los alumnos de esta clase nos interesamos por sacar buenas notas

The students in this class are interested in getting good grades

32. El ambiente que hay en clase, es casi siempre tranquilo

The class atmosphere is almost always calm

33. Mi clase es un lugar agradable (me gusta estar en mi clase)

My classroom is a nice place (I like being in my classroom)

34. Los profesores están satisfechos con "la marcha" general de los alumnos de este grupo clase

The teachers are satisfied with the general progress of the students in this class group
23. Todos los estudiantes de nuestro grupo-clase estamos implicados en la toma de decisiones que nos afectan

All of the students in our class group are involved in the decisions that affect us

24. Los estudiantes colaboramos entre nosotros $(*)$ The students work together

25. En nuestro grupo-clase se favorecen debates entre nosotros $\left(^{*}\right)$

Debate between students is fostered in this class group

26. Los profesores animan a los estudiantes que quieren hacer las cosas de manera original

The professors encourage students who want to do things in an original way

27. Los profesores llevan a cabo actuaciones para que en el aula se cumplan las normas de comportamiento $(*)$

The professors take action to ensure that rules of behaviour are followed in the classroom

28. En nuestro grupo-clase, los profesores y los estudiantes nos preocupamos los unos de los otros $(*)$

In our class group the professors and students are concerned about each other

29. El profesorado ignora nuestras necesidades formativas

The professors ignore our training needs

30. No existe ambiente de colaboración entre el profesorado y el estudiante

There is no atmosphere of cooperation between the professors and the student

31. Los estudiantes de nuestro grupo-clase nos interesamos por formarnos y ser profesionales competentes $(*)$

The students in our class group are interested in training and becoming competent professionals

32. El ambiente que hay en las aulas es casi siempre tranquilo y sin conflictividad

The atmosphere in the classrooms is almost always calm and free from conflict

33. La Facultad es un espacio agradable (*)

The Faculty is a nice place to be

34. Los profesores se muestran satisfechos con la "marcha" general de los estudiantes de nuestro grupo-clase

The professors are satisfied with the general progress of the students in our class group 
35. La clase es un espacio físico confortable (luz adecuada, organizada, no hay ruidos...) The classroom is a comfortable physical space (adequate light, organized, no noise...)

36. Hay una buena comunicación entre nuestros profesores

There is good communication between our teachers

\section{Los profesores se sienten orgullosos de esta clase \\ The teachers are proud of this class}

38. En este grupo aprendemos muchas cosas interesantes (a nivel personal y de conocimientos)

In this group we learn a lot of interesting things (both personal and academic)

39. Los alumnos nos preocupamos mucho del progreso de esta clase

The students are very concerned about the progress of the class

40. Algunos alumnos forman pequeños grupos con sus íntimos amigos y no les importa el resto de compañeros

Some students form small groups with close friends and do not care about their other classmates

41. El tutor ha explicado claramente cuáles son las normas de funcionamiento de esta clase

Our class teacher has clearly explained the class rules

42. El tutor ha explicado claramente que sucederá si un alumno rompe una norma Our class teacher has clearly explained what will happen if a student breaks a rule

\section{En esta clase existen demasiadas reglas y} normas

There are too many rules and regulations in this class

44. En esta clase se producen alborotos con frecuencia

There are frequent disturbances in this class
35. Las aulas son confortables (iluminación, temperatura, sonoridad adecuada...)

The classrooms are comfortable (lighting, temperature, adequate sound...)

36. Hay muy buena comunicación entre los estudiantes de diferentes cursos

There is very good communication between students in different years

37. Los profesores se sienten satisfechos de este grupo-clase

The professors feel satisfied with this class group

38. En nuestra Facultad nos formamos como profesionales y como personas

In our Faculty we are trained as both professionals and people

39. Los estudiantes nos preocupamos del progreso de nuestro grupo-clase $(*)$

The students are concerned about the progress of our class group

40. Algunos estudiantes forman pequeños grupos excluyentes y no les importa el resto de compañeros

Some students form small exclusive groups with close friends and do not care about their other classmates

41. A los estudiantes se nos ha explicado claramente cuáles son las normas de funcionamiento de la Facultad (*)

The students have had the Faculty rules explained to them clearly

42. A los estudiantes se nos ha explicado claramente qué pasa si un alumno incumple una norma en el aula (*)

The students have had it clearly explained what happens if a student breaks a rule in class 43. Echo en falta reglas y normas de comportamiento explícitas en la Facultad

I wish there were explicit rules and regulations for behavior at the Faculty

44. En nuestro grupo-clase hay demasiado alboroto (que impide el buen funcionamiento)

There are too many disturbances in our class group (impeding it from functioning correctly)

(*) Items comprising the final version of the CSCS-U 
Carles Rostan Sánchez et al.

[This page intentionally left blank] 